シンポジウム II -5

\title{
非ホジキン悪性リンパ腫治療における $\mathrm{rhG}-\mathrm{CSF}$ 投与の臨床病態に与える影響
}

\author{
岡部 實裕 ${ }^{1)}$, 桜田 恵右 ${ }^{1)}$, 小林 正伸 ${ }^{1)}$ \\ 済木 育夫 ${ }^{2)}$, 松野 一彦3), 皆川 知紀 ${ }^{4)}$ \\ 1) 北海道大学医学部第三内科教室 \\ 2 ) 北海道大学免疫科学研究所化学部門 \\ 3 ) 北海道大学医学部中央険査部 \\ 4 ) 北海道大学医学部細菌学教室
}

Clinical effect of recombinant human granulocyte-stimulating factor in non-Hodgkin malignant lymphoma

Mihiro Okabe ${ }^{1)}$, Keisuke Sakurada ${ }^{1)}$, Masanobu Kobayashi ${ }^{1)}$
Ikuo Saiki ${ }^{2)}$, Kazuhiko Matsuno ${ }^{3)}$ and Tomonori Minagawa ${ }^{4)}$

The Third Department of Internal Medicine ${ }^{1)}$, The Department of Laboratory Medicine ${ }^{3)}$ and The Department of Microbiology4), School of Medicine, and The Section of Chemistry2), Institute of Immunological Science, Hokkaido University

To evaluate the clinical effect by administration of recombinant human granulocyte -stimulating factor (rhG-CS) post chemotherapy in non-Hodgkin malignant lymphoma (NHL), fifteen patients with NHL were subjected to this study. In patients with CHOP, VEPA or M-FEPA combination chemotherapy, administration of rhG-CSF ameliorated the decrease in absolute neutrophil count after the cytotoxic chemotherapy and was effective for reducing infection complications associated with neutropenia. These clinical effects were observed in ProMACE/CytaBOM regimen as the third generation chemotherapy. Furthermore, administration of rhG-CSF post cytotoxic chemotherapy increased peripheral hematopoietic progenitor cells, thus suggesting promising therapeutic potential for harvest for autografting.

No adverse effects were observed except for one patient complaining of a bone pain of mild degree. rhG-CSF showed no effect on platelet glycoprotein expression and aggregation.

Recently, it has been reported that blood neutrophils may synthesize mRNA and proteins important in inflamation including variuos cytokines such as interleukin-1 (IL-1), interferone-alpha (IFN- $\alpha$ ) and tumor necrosis factor- $\alpha$ (TNF- $\alpha$ ). Administration of rhG-CSF provided no fluctuation of serum IFN- $\alpha$ level except for one case with peripheral T-cell lymphoma expressing IFN-transcript in peripheral neutrophils prior G-CSF treatment. Slight elevations of serum TNF- $\alpha$ level associated with rhG-CSF treatment in two patient, although the present study showed no evidence that their neutrophils 
produced TNF- $\alpha$. These results suggested that further study will be needed to clarify in vivo significance of G-CSF in the cytokine network system.

Finally, we studied on anti-tumor effect of administration of rhG-CSF in CDF1 mice inoculated with L5178Y-ML25 lymphoma cells. Administration of rhG-CSF inhibited the liver metastasis and prolonged the overall survival, thus suggesting the hyposis that the use of rhG-CSF in some patients with NHL might control the disease with activation of netrophils.

Key Words:rhG-CSF, Non-Hodgkin lymphoma, Platelets, Cytokines, Anti-tumor activity

\section{緒}

非ホジキン・リンパ腫(NHL)に対する抗癌化学療 法は CHOP 療法や VEPA 療法に代表される第 1 世 代の治療から，非交叉耐性の多種類の薬剤を短期間 に投与することにより治療を含め治療成績の向上を 目指す第 3 世代の治療へと移り变わりつつある1)。 しかし dose intensity の高い治療を遂行するら兄 で，骨髄抑制に伴う好中球減少が薬剂強度に対する 制約要因の一つとなって扣り，多施設第 2 相試験を 終えた遺伝子組換ヒト granulocyte-colony stimulating factor (G-CSF)の併用の重要性が指摘され ている。

第 2 相試験に括いて私達の教室で G-CSF を使用 した NHL 症例の解析を中心に, NHL 治療に怙け る rhG-CSF 使用の意義と臨床病態に与える影響に ついて検討したので報告する。

\section{症例と方法}

当科で経験した中等悪性度群以上の 15 症例の NHL (年令分布, 21 72歳) に打いて患者の承諾を 得て rhG-CSF を抗癌剂投与後 $2 \sim 3$ 日後から投与 した。延べ46コースの化学療法後の rhG-CSF 併用 の有無に上る白血球減少と感染予防効果について検 討した。cDNAを大腸菌に発現させたものと chinese hamster の卵巣細胞 (CHO 細胞) に発現さ せた $\mathrm{rhG}-\mathrm{CSF} \beta$ が本邦では使用可能であり,それら のいずれかを用いて検討した。

造血幹細胞コロニー形成：患者末梢血をへパリン 採血し Ficoll-Conray 比重遠沈法により単核球を 分離した。コロニーアッセイは軟寒天 1 層法により
施行した2)。

血小板膜 glycoprotein 及び凝集能の測定：患者 末梢血を $15 \%$ acid-citrate-dextrose 溶液にて採血 し，100g，15分遠心にて platelet rich plasma を回 収，それを $350 \mathrm{~g} ， 20$ 分遠心し血小板を得た。血小板 表面の各種 glycoproteinの発現は単クローン抗体 を用いた flow cytometerにより，血小板凝集能は Dual aggregometer 用いて測定した。

血清サイトカイン測定: IFN- $\alpha$ の測定はヒト FL 細胞と vesicular stomatitisウイルスを用い dye-binding 法に依った ${ }^{3)}$ 。IFN- $\gamma$ の測定はCentcor radioimmunoassay test kit (Centcor 社), TNF- $\alpha$ の測定は IRMA 社の radioimmunoassay test kitによっだ)。

好中球分離と IFN $-\alpha$ 及び TNF- $\alpha$ transcripts の検出：一パリン採血した末梢血に $3 \%$ キスデトラ ン, $1 \%$ ゼラチ加PBSを加兄 1 時間静置し赤血 球を沈澱させ，上澄より単核球を含む好中球層を回 収し Ficoll-Conray 比重遠沈法により好中球を得 た。RNAzol法によりRNAを抽出し, totalRNA20 $\mu \mathrm{g}$ を $7 \%$ ホルムアルデハイドを含む $1 \%$ ガロースにて電気泳動し biodyne 膜 (Pall 社)にblot した ${ }^{5)}$ 。 nick-translationにより $32 \mathrm{p}$ を標 識した IFN- $\alpha$ 1cDNA probe ${ }^{6}$ (Hif-2h plasmid, 長 田重一博士〈大阪バイオサイエンスセンター〉御供 与), 5'-end labelingにより標識した合成オリゴヌ クレオチド TNF- $\alpha$ probe とハイブリドし mRNA の発現を検索した。

マウスの系に怙ける rhG-CFS の抗腫㵣活性の検 討：CDF1 マウスに同系の L5178Y-ML25T リンパ 腫細胞 $\left(3 \times 10^{4}\right)$ を静注接種し, 翌日より $\mathrm{rhG}$ - 
Case K.K. NHL (diffuse large cell, CS III A)

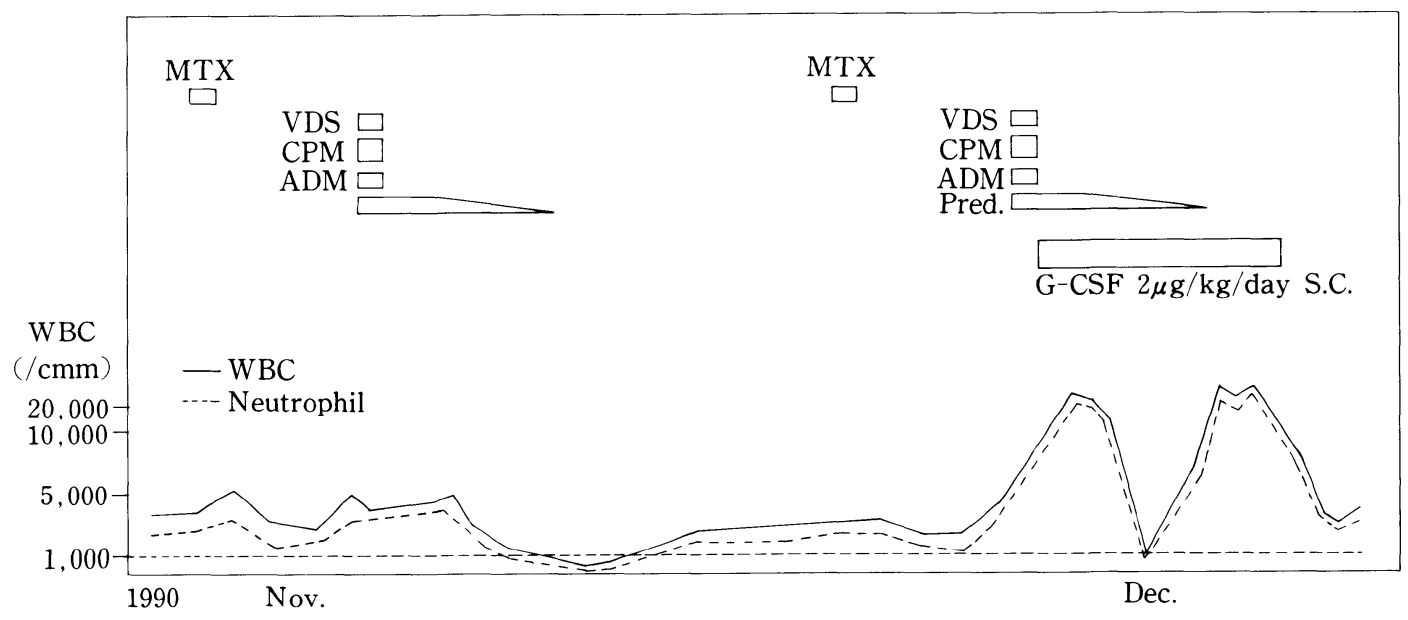

图 1 rhG-CSF 投与による末梢白血球の二峰性増多

M-FEPA 療法後に rhG-CSF 2 週間皮下注投与した。

VDS, ビンデシン；GMP, サイクロフォスファマイド；ADM, アドリアマイシン；MTX, メントレキセート

$\mathrm{CSF} 2 \mu \mathrm{g}$ を 7 日間連日静注投与した。servival の検 討と肝を主に転移病変について検討した ${ }^{7)}$ 。

結果

rhG-CSF の末梢白血球増多作用と末梢血循環造 血幹細胞への作用の検討：図 1 に M-FEPA 療法 ${ }^{8)}$ 後 $\mathrm{rhG}-\mathrm{CSF}$ を投与 ( $2 \mu \mathrm{g} / \mathrm{kg} / \mathrm{day}$, S.C. $)$ した NHL（び慢性大細胞型, 臨床病期 IIIA) 症例に扔 ける末梢白血球数の变動を示した。治療後 rhG-CSF を投与しない観察期と比べ投与期では白血球数最低 值の上昇や回復日数の短縮が明らかであった。治療 後 $r h G-C S F$ によ末梢白血球は投与直後より reserve pool からの動員に基づく一過性の増加を示 した後，一旦低下し $7 \sim 10$ 日後に G-CSF 反応性の 造血幹細胞の増殖, 分化に基づき再度増加寸る二相 性の増加パターンを示した。CHOP 療法後 rhG$\mathrm{CSF}(5 \mu \mathrm{g} / \mathrm{Kg} / \mathrm{day}, \mathrm{IV})$ 投与症例に扣いても同様 な二相性増加パターンを示した。多施設臨床第 2 相 試験の結果より rhG-CSF の至適最少有効量は皮下 注で $75 \mu \mathrm{g} / \mathrm{body}$, 静注では $200 \mu \mathrm{g} / \mathrm{body}$ 程度と考光 られるが，それ以下の $16 \mu \mathrm{g} /$ body の少量静注投与で も, 投与直後の reserve pool からの末梢血への動員 作用が認められた。

抗癌化学療法後 $\mathrm{rhG}-\mathrm{CSF}$ 投与による 1 週間以降
の末梢白血球数上昇に一致し末梢血循環造血細胞コ ロニ一数の増加が認められた(図 2)。検索例の一部 を除き，G-CSF 投与10日前後以降には CFU-Mix, CFU-G, BFU-E のいずれもが健康人の骨髄単核球 に匹適するコロニー形成数を示した。

NHL 治療にお法る rhG-CSF 併用の有効性の検 討: 各種化学療法において, 至適有効量の rhG-CSF （皮下注 $125 \mu \mathrm{g} /$ body あるいは静注 $250 \mu \mathrm{g} /$ body の いずれか）を治療後投与し末梢血白血球減少に対す るレスキュー効果について検討した(表 1 )。第 1 世 代に準じた CHOP 及び VEPA 療法や M-FEPA 療 法に沶いて, rhG-CSF 投与による白血球数最低值の 上昇, 白血球数 $1000 / \mu 1$ 以下の持続日数及び $2000 / \mu 1$ 以上の回復までに要する日数の短縮が認められた。 第 3 世代に準ずるProMACE/CytaBOM 療法》は 他種治療に比較し骨髄抑制、白血球減少が最も強い 傾向を示したが, G-CSF 投与の併用により白血球最 低值，骨髄抑制の期間を著明に改善した。

私達の教室の過去10年間の中及び高悪性度群 NHL81症例は完全寛解率 $54 \%, 5$ 年生存率は $46 \%$ で あった。CHOP 療法と第 3 世代の MACOP-B 療法 の治療成績の比較検討では，現在までのところ， MACOP-B 療法は当初期待された十分な予後の改 善をもたらしていない(図 3)。この一つの要因とし 


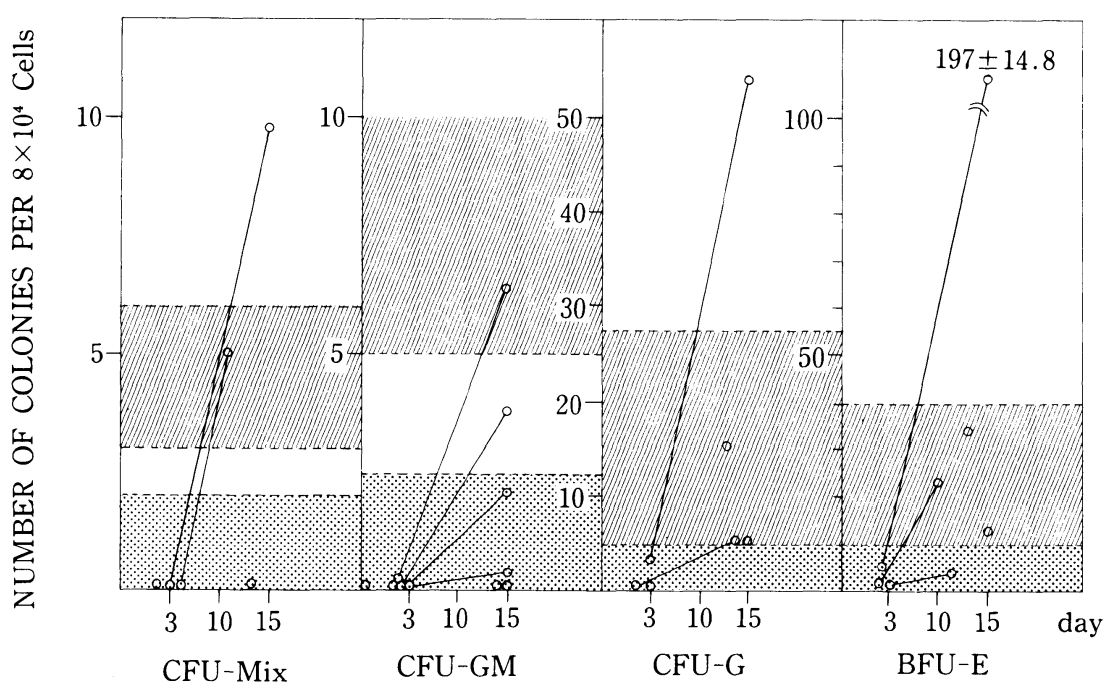

図2 rhG-CSF の末梢循環造血幹細胞增加作用, 各種化学療法後 rhG-CSF を投与し末梢

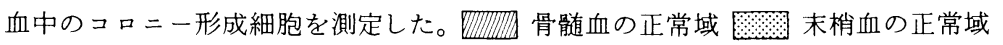

表 1 NHL 化学療法に伴う白血球減少に対する $\mathrm{rh}-\mathrm{G}-\mathrm{CSF}$ 投与の臨床効果

\begin{tabular}{|c|c|c|c|c|c|}
\hline 化学療法 & $\begin{array}{l}\text { G-CSF 投与 } \\
\text { の有無 }\end{array}$ & $\begin{array}{l}\text { 白血球数 } \\
\text { 最低値 }\end{array}$ & $\begin{array}{l}\text { 白血球数 } 1,000 / \mathrm{mm}^{3} \\
\text { 末満の日数 }\end{array}$ & $\begin{array}{l}\text { 白血球数 } 2,000 / \mathrm{mm}^{3} \\
\text { 以上の回復日数 }\end{array}$ & $\begin{array}{l}\text { 治療後感染 } \\
\text { 症の有無 }\end{array}$ \\
\hline \multirow[t]{2}{*}{$\mathrm{CHOP}$} & 無 $(n=9)$ & $1,016 \pm 481$ & $2.3 \pm 2.4$ & $11.8 \pm 2.3$ & $2 / 9$ \\
\hline & 有 $(\mathrm{n}=6)$ & $1,825 \pm 476$ & 0 & $2 \pm 2.1$ & $0 / 6$ \\
\hline \multirow[t]{2}{*}{ VEPA-B } & 無 $(\mathrm{n}=6)$ & $1,350 \pm 354$ & $0.3 \pm 0.7$ & $5 \pm 4.9$ & $4 / 6$ \\
\hline & 有 $(\mathrm{n}=3)$ & $3,400 \pm 600$ & 0 & 0 & $0 / 3$ \\
\hline \multirow[t]{2}{*}{ M-FEPA } & 無 $(\mathrm{n}=8)$ & $857 \pm 244$ & $2.6 \pm 2.4$ & $7.9 \pm 2.9$ & $2 / 8$ \\
\hline & 有 $(\mathrm{n}=7)$ & $2,100 \pm 874$ & 0 & $1.6 \pm 1.4$ & $0 / 8$ \\
\hline \multirow{2}{*}{$\begin{array}{l}\text { Pro MACE/ } \\
\text { Cyta BOM }\end{array}$} & 無 $(\mathrm{n}=3)$ & $550 \pm 50$ & $9.5 \pm 0.5$ & $14.5 \pm 2.5$ & $2 / 3$ \\
\hline & 有 $(\mathrm{n}=4)$ & $1,800 \pm 578$ & $0.25 \pm 0.43$ & $1.5 \pm 2.0$ & $1 / 4$ \\
\hline \multirow[t]{2}{*}{ 合 計 } & 無 $(n=25)$ & & & & $10 / 25$ \\
\hline & 有 $(n=21)$ & & & & $1 / 21$ \\
\hline
\end{tabular}

ては骨髄抑制による白血球減少が強く，かつ，その 回復の遷延のため十分な薬剤量をもって治療を施行 し得ないことが関与していると考えられた（データ 未揭載)。図 4 にProMACE/CytaBOM 療法を施行 した症例を示した。第 1 コースの治療で著明な白血 球减少と遷延がみられたため, 次回コースより G$\mathrm{CSF}$ 投与を併用し薬剤量を減量せずに安全に治療
を遂行し得た。上上の結果は $\mathrm{G}-\mathrm{CSF}$ の併用により 第 3 世代の治療を十分な薬剂強度をもって安全に施 行し得ることを示唆した。

$\mathrm{G}-\mathrm{CSF}$ 投与による副作用の検討：今回の検討で は投与を中断せざるを得ないような重篤な副作用は みられず， 1 症例で G-CSF 投与直後の骨痛がみら れたのみであった。 


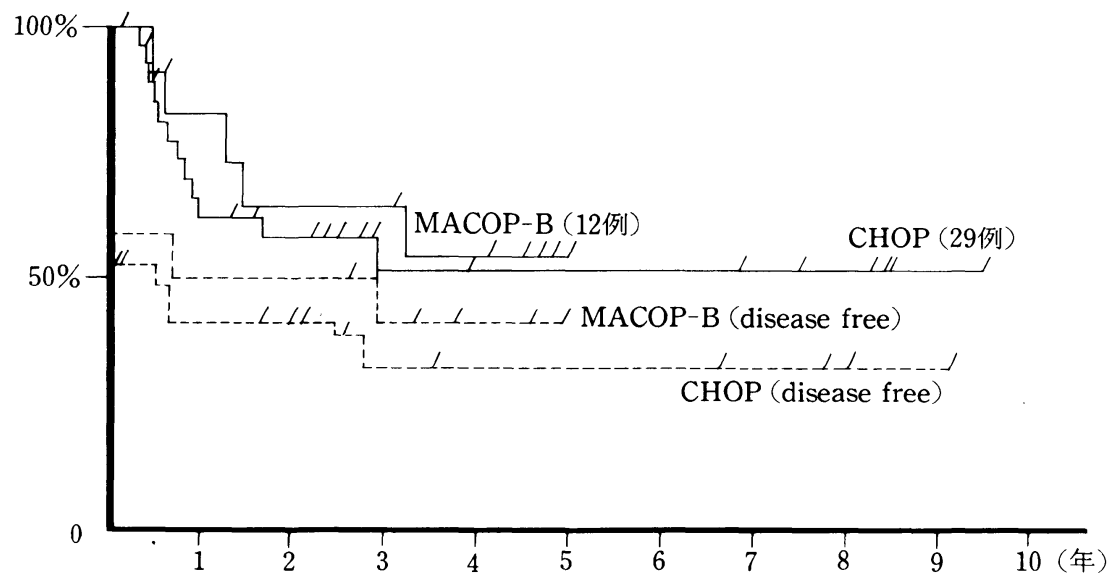

図 3 CHOP, MACOP-B 施行例別生存曲線, 1979-1988年の当科に括ける NHL81 症例 について検討した。CHOP と MACP-Bに拈ける CR rate と 5 年生存率は各々, 52 \%, 50\%と $58 \%, 53 \%$ でった。

Case Y.N. $56 \mathrm{y}^{-} \mathrm{o}$, male NHL (diffuse large cell, CS III B)

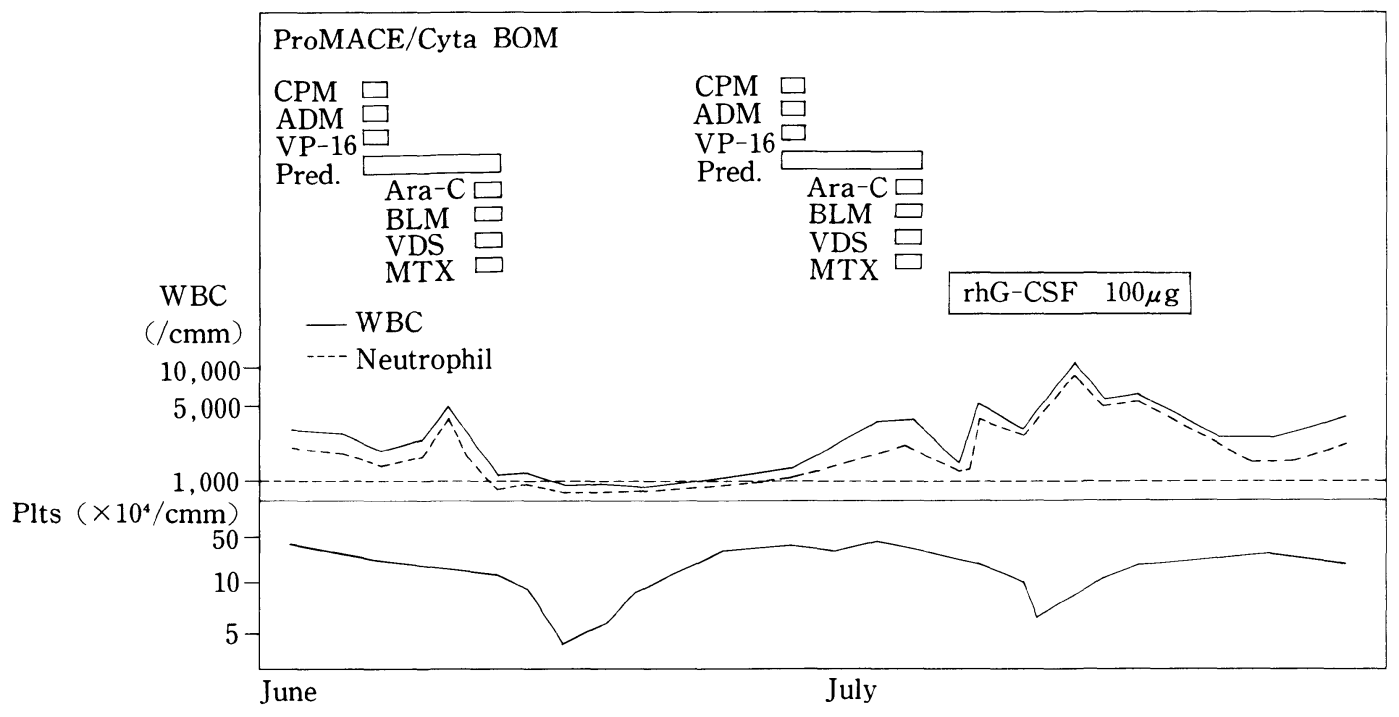

図 4 ProMACE/CytaBOM 療法後の rhG-CSF 投皮症例 治療終了後10日間 rhG-CSFを皮下注した。BLM，ブレオマイシン

Lindeman らは臨床第 1 相試験の報告のなかで 60 $\mu \mathrm{g} / \mathrm{Kg}$ の超大量の $\mathrm{rhG}-\mathrm{CSF}$ 静注投与により血小 板 glycoprotein IIb/IIIa (CD41)の発現が一過性に 減少すると述べている ${ }^{10)}$ 。至適有効量の $\mathrm{G}-\mathrm{CSF}$ 投
与に拈いても血小板系に何らかの影響があるかどら か検討した。 rhG-CSF $125 \mu \mathrm{g} /$ body 皮下注 3 時間後 の血小板について単クローン抗体により flow cytometoryにて検索した（図 $5 \mathrm{~A}$ )。血小板 glyco- 


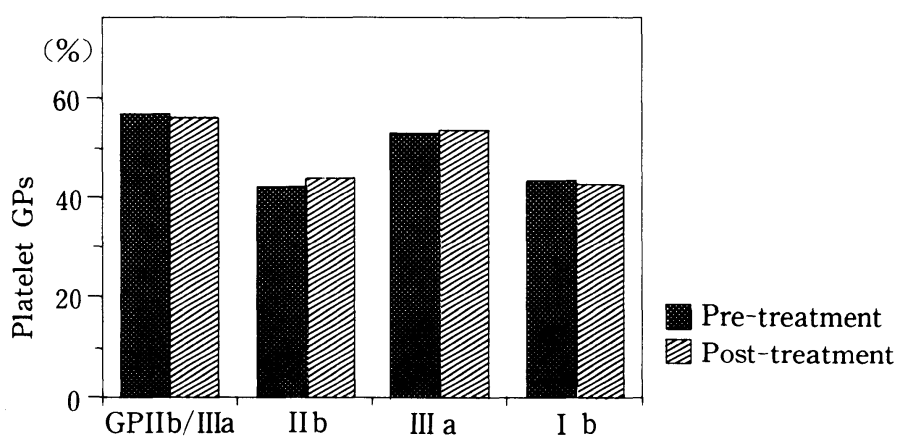

図 5 A rhG-CSF の in vivoに拈ける血小板に対する影響

A : glycoprotein に対する影響

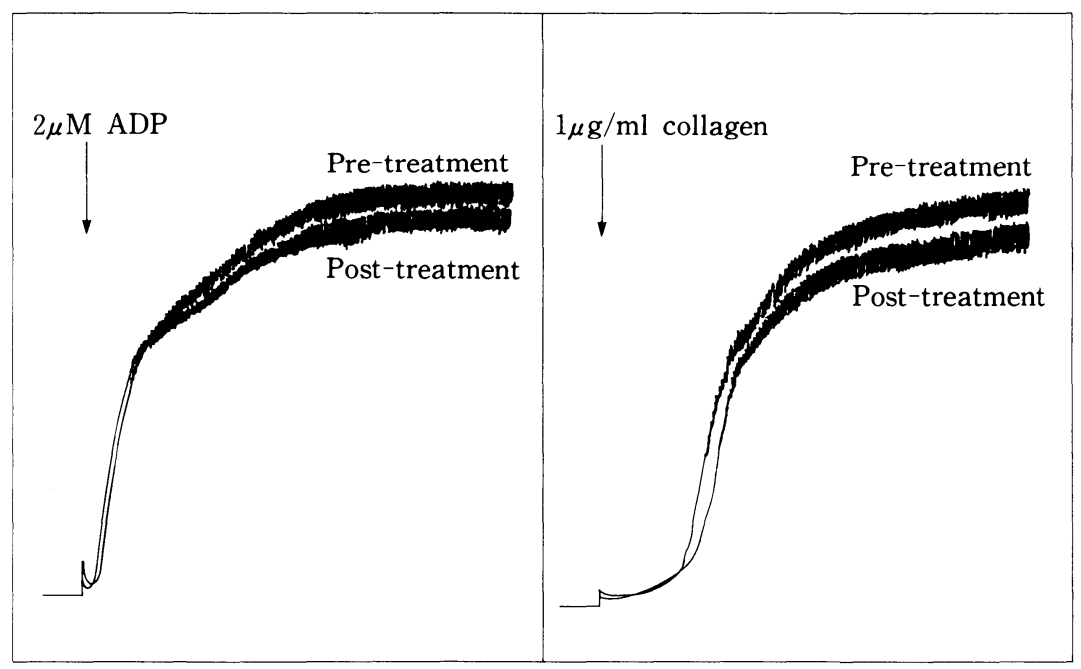

図 $5 \mathrm{~B}$ ：凝集能に対する影響

protein IIb/IIIa, IIb, IIIa, Ibいずれにおいても発 現低下は認められなかった。さらに血小板凝集能に ついても検索したが，凝集能の障害はみられなかっ た（図 5 B)。

rhG-CSF 投与に伴う血中サイトカインの変動： G-CSF は造血幹細胞に作用し好中球産生を高める とともに好中球機能を活性化させるが, rhG-CSF 投 与を受けた症例では好中球の FMLP-刺激によるス 一パーオキサイド産生能が亢進していることが明ら かにされている(1112)。最近, 活性化された好中球が IFN- $\alpha, \mathrm{TNF}-\alpha, \mathrm{IL}-1$ などのサイトカインを産生 することも報告されている(13) 15)。そこで, rhG-CSF
投与に伴う血清サイトカインの変動について検索し た。血清 IFN- $\gamma$ 值には $\mathrm{rhG}-\mathrm{CSF}$ 投与に伴ら変動は 認められなかった。血清 IFN- $\alpha$ は $\mathrm{rhG}-\mathrm{CSF}$ 投与 4 症例で経過を追って測定した。G-CSF 投与前のこれ らの症例や健康人の血清では検出感度以下であった が，一症例で rhG-CSF 投与14日目に軽度の上昇を 示した(図 $6 \mathrm{~A}$ )。G-CSFにより in vivo で活性化さ れた好中球の IFN- $\alpha$ 産生に基づくものかどらかに ついて, この症例の $\mathrm{rhG}-\mathrm{CSF}$ 投与後の好中球を回 収し in vitro培養に打ける IFN- $\alpha$ 産生能とその transcriptの発現について検討した。培養液中に IFN- $\alpha$ 活性は検出されなかったが, ノザン法による 


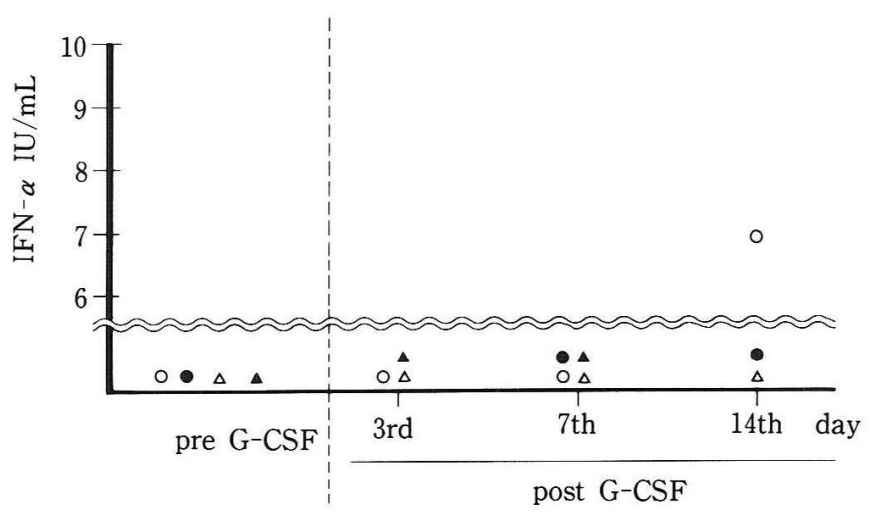

図 6 A rhG-CSF 投与に伴う血清 IFN- $\alpha$ 値(A)とその上昇を示した症例 の好中球分画の IFN- $\alpha$ mRNA 発現(B)

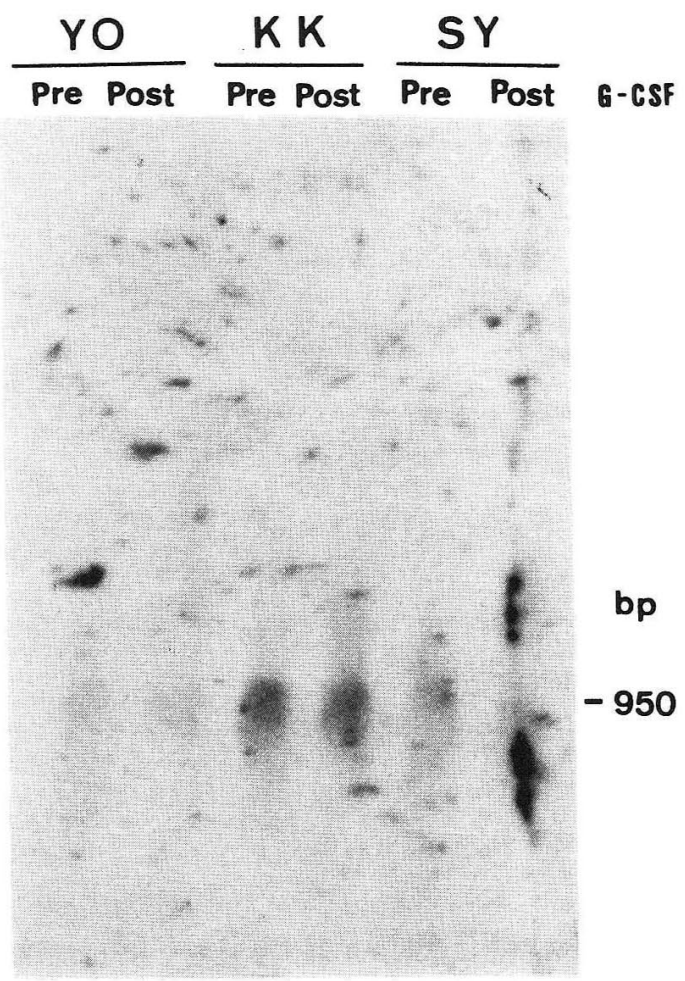

図 6 B

IFN- $\alpha$ mRNA の検討では, 本症例の好中球では G$\mathrm{CSF}$ 投与前, 後のいずれにおいても $950 \mathrm{bp}$ の IFN$\alpha \mathrm{mRNA}$ の発現が認められた（図 6 B)。しかし, rhG-CSF 投与を受けた他の NHL2 症例では IFN$\alpha$ transcript は検出されなかった。
$\mathrm{rhG}-\mathrm{CSF}$ 投与に伴 $う$ 血清 $\mathrm{TNF}-\alpha$ 值の変動に関 して 2 症例において検索した。四 7 に示したように 延べ 3 回の測定はいずれに拈いても rhG-CSF 投与 に伴ら血清 TNF- $\alpha$ の軽度上昇を示した。

マウスの系に扣ける rhG-CSF の抗腫瘍活性の検 討：悪性リンパ腫に対する G-CSF 投与がもたらす さらなる臨床的意義として G-CSF 自体に抗腫瘍活 性があるかどうかは興味深い問題であるが, G-CSF の臨床使用の歷史も浅いため抗腫瘍活性を介し予後 の改善をもたらす可能性の有無は明らかでない。そ こで私達は同系マウス CDF1に $\mathrm{T}$ ーリンパ腫細胞株 L5178Y-ML25 を接種した後, rhG-CSFを 7 日間投 与し無投与群と比較した。G-CSF 無投与群では肝へ の転移が著明であり22日以内に全例が死亡した。一 方，G-CSF 投与群では肝転移は抑制され50\% survival は60日と有意に延長した（図 8 ）。

\section{まとめと考察}

悪性リンパ腫とサイトカインの関連性はその病態 形成のみならず病因論学的視点より重要性が指摘さ れつつある。一方, G-CSF をはじめとする造血細胞 の増殖と分化に関与する遺伝子組換型サイトカイン が遺伝子工学的技法により人量生産が可能となり, その臨床応用による悪性リンパ腫治療に与える意義 が指摘されてきている。ヒト膀胱癌細胞よりクロ一 ニングされたヒト G-CSFcDNAの塩基配列より, ヒト G-CSF は mRNA の選択的スプライシングに 基づき $\alpha$ 型と $\beta$ 型の 2 種類の糖タンパク質が翻訳 される。177個と173個のアミノ酸よりなる $\alpha$ 型と $\beta$ 


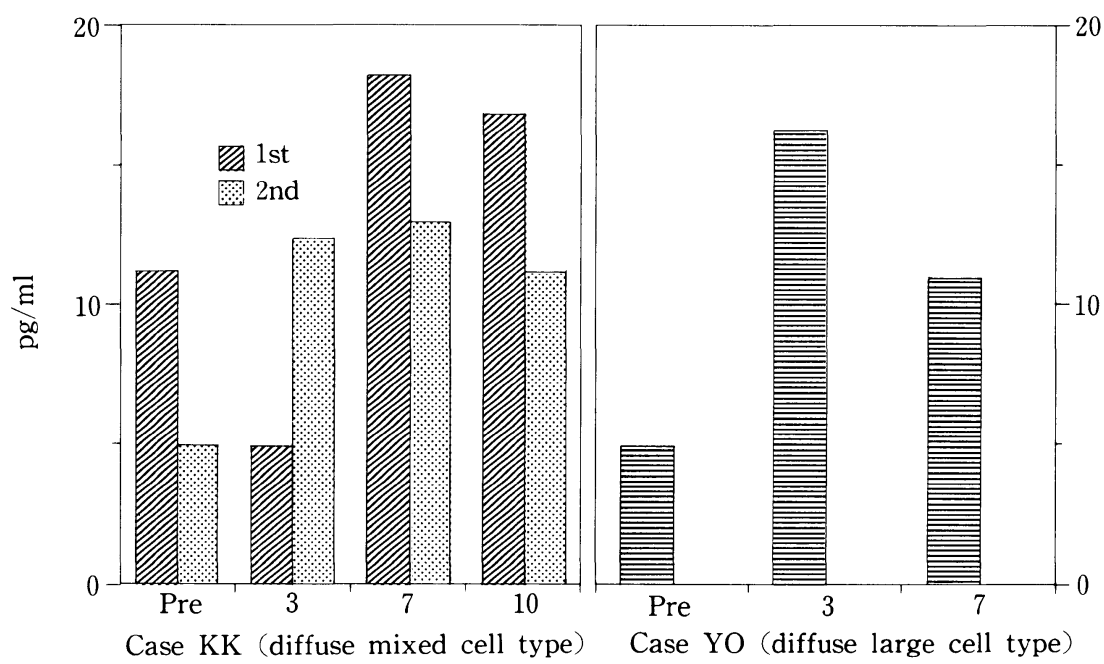

目 $7 \mathrm{rhG}-\mathrm{CSF}$ 投与に伴う血清 $\mathrm{TNF}-\alpha$ 值の変動

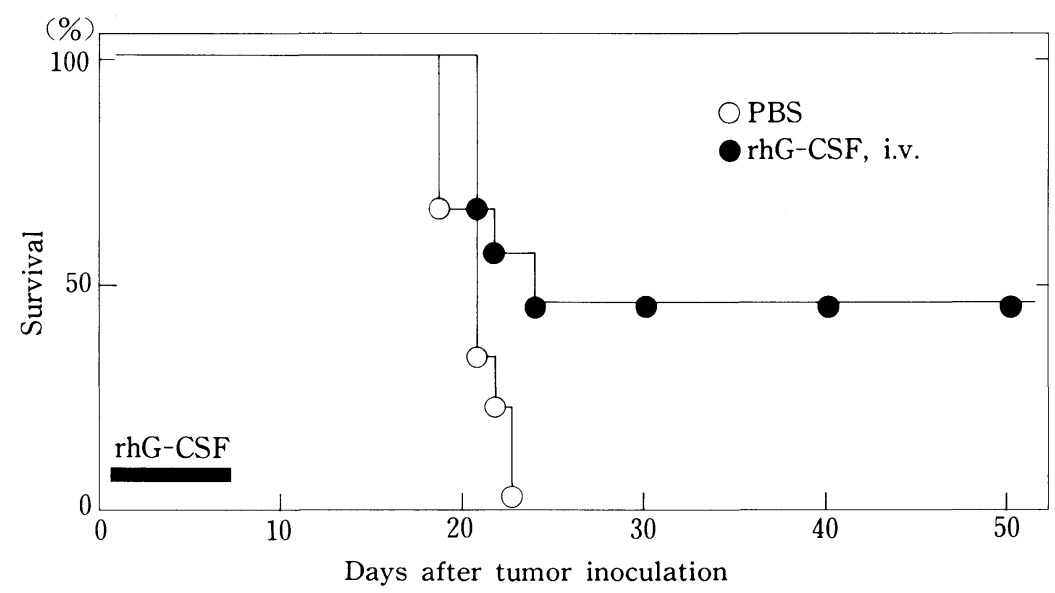

図 8 L5178Y-ML25 リンパ腫細胞接種 CDF1 マウスにおける rhG-CSF 投与の生存に与 方る影響

型の一次構造の差異は $\mathrm{N}$ 端側35番アミノ酸部位に おける 3 アミノ酸の欠出/㨂入に基づき, $\beta$ 型が $\alpha$ 型より少なくとも20倍以上生理活性が強いとされて いる15)。本邦に执いては，大腸菌に発現させたもの 2 種類と native なとト G-CSF と同じく糖鎖を含 有する chinese hamster の卵巣細胞に発現させた rhG-CSF の使用可能であり, 悪性リンパ腫治療に伴 万白血球減少に対する臨床多施設第 2 相試験が各々 において捛こなわれた。いずれにおいても，CHOP
療法施行後の白血球減少に対するレスキューと感染 予防に優れた効果を示すことが既に明らかにされて (いる(1)17)。今回, 私達の施設に打いても rhG-CSF の 併用は化学療法後の白血球減少の程度を著明に改善 するとともに治療後の感染症合併の予防に優れた効 果を示した。更に, ProMACE/CytaBOM 療法に打 いても rhG-CSF 投与により白血球減少の程度は rhG-CSF を併用した第 1 世代の治療と同程度にレ スキューされることが分かった。このことは, rhG- 
CSFを併用することにより十分な薬剤強度をもっ て第 3 世代の治療を安全に施行し得る可能性のひと つを提供するといら点で重要である。しかし，NHL 治療に打ける治療強度の増強は細胞性免疫能障害, 口腔及び消化管粘膜障害の増加による内因性感染症 増加の可能性, 好中球機能障害の増強や骨髄抑制以 外の副作用の増強をもたらす。これらの点を考える 之, rhG-CSF 併用により末梢白血球数のみを安全域 に調整し安易に治療強度を高めることの危険性は現 時点では否定できない。今後, これらの点を総合的 に評価，検討しながら，NHLの治癒を標的とした rhG-CSFなどのサイトカインを併用した治療法が 確立されるものと考えられる。

化学療法後の G-CSF 投与による末梢白血球数の 増加は二峰性の増殖動態を示した。rhG-CSF 投与直 後より末梢白血球は急激に増加した後, 一旦低下し, 10 日前後より再度増加を示す。前者の増加は骨髄の reserve プールからの動員であり, 後者の増加は $\mathrm{G}^{-}$ $\mathrm{CSF}$ に反応性を有する造血幹細胞の增殖と分化に 基づくものと考えられる。このような末梢白血球数 の変動と関連し, 10 日前後より末梢血循環造血幹細 胞の増加が認められた。増加造血幹細胞は CFU-G のみならず, CFU-Mix, CFU-GM や BFU-E の増 加も認められ，そのいずれに打いても G-CSF 投与 10 日以降では骨髄中の造血幹細胞数に匹適するコロ ニー数を示す症例が多かった。化学療法による骨䯣 抑制の回復期に GM-CSF P G-CSF の投与が末梢 血に循環造血幹細胞を動員する機序は不明である が, 今回の検討では, 化学療法後の rhG-CSF 投与に より末梢血循環造血幹細胞を harvestしておき intensive chemotherpy の back-up や自己骨髄移 植に応用することは十分可能であると考えられた。 但し, 同様の化学療法と rhG-CSF 併用のプロトコ ールに抢いて, 末梢血循環造血幹細胞の増加が認め られない症例が一部にみられたことにより，今後， その機序や動態の解析が必要と考えられた。

多施設臨床第 2 相試験同様に, 私達の今回の検討 に颃いても投与を中止せざるをえないよらな重篤な 副作用はみられなかった。大量の $\mathrm{rhG}-\mathrm{CSF}$ 投与の 場合には一過性の血小板減少やその表面 glycoprotein IIb/IIIa の発現の減少が報告されており ${ }^{10)}$, また，in vitroにおいて種々の刺激因子により活性 化された好中球はセリンプロテアーゼなどの産性を 介して血小板凝集に影響を与えるとする報告もみら れる18)ため, 至適有効量の $\mathrm{rhG}-\mathrm{CSF}$ 投与に拈いて
血小板系への影響がみられるかどうかについて検討 した。しかし, 血小板数, 各種 glycoprotein の発現 及び凝集能に対する影響は認められなかった。

最近, 活性化された好中球が plasminogen activator 等の regulatory mediator の産生, 分泌の みならず種々のサイトカイン-IFN- $\alpha, \mathrm{TNF}-\alpha, \mathrm{IL}$ 一1などを産生することが報告されてきている。 rhG -CSF 投与の好中球に対する影響は量的増加作用に とどまらず，質的な面での活性化作用も明らかにさ れてきている。そこで, rhG-CSF 投与により活性化 された好中球の増加が，これらのサイトカインの産 生を介して病態を修飾する可能性や生体内の “サイ トカイン ネットワーク”に対する影響の可能性も 推察されるため, rhG-CSF 投与に伴う血中サイトカ インの変動について検討した。血清 $\mathrm{IFN}^{-} \boldsymbol{\gamma}$ は $\mathrm{rhG}^{-}$ $\mathrm{CSF}$ 投与と関連した变動は示さなかったが, 血清 IFN- $\alpha$ は検索 4 症例中 1 症例で, また, 血清 TNF - $\alpha$ は 2 症例に拈ける延べ 3 回の検索で, 全例に rhG -CSF 投与に伴う軽度の上昇を示した。 rhG-CSF 投 与症例の好中球の培養上清中には有意な TNF- $\alpha$ 活性は検出されず，好中球分画の TNF- $\alpha$ transcript の発現はノザン法では検出されなかったこと より血清 TNF- $\alpha$ 值の上昇が G-CSF により活性化 された好中球に由来するか否かについては今回の検 討では明らかではなかった。一方, IFN- $\alpha$ 上昇を示 した症例より回収した好中球は950bpの major type の IFN- $\alpha$ mRNAの発現を示した。本症例は 末梢 T-細胞リンパ腫であり, その好中球は G-CSF の投与前に怙いても IFN- $\alpha$ mRNA の発現がみられ た。このことは腫瘍性 T-細胞のサイトカイン産生を 介した好中球の活性化状態が既に存在していた可能 性を示唆すると考えられた。Shirafuji らは, in vitro に打ける $\mathrm{rhG}-\mathrm{CSF}$ 刺激は好中球の IFN- $\alpha$ の産生, 分泌及びその mRNAの発現を誘導することを明ら かにし, neutropoiesis をはじめとする造血の調節機 構における IFN- $\alpha / \mathrm{G}-\mathrm{CSF}$ system の関与を推察し ている12)。生体内に抢ける“サイトカインネットワー ク”system の解明は今後の課題ではあるが, 今回の 検索で認められた $\mathrm{rhG}-\mathrm{CSF}$ 投与に伴う血清 IFN$\alpha$ TNF- $\alpha$ 值の変動の生体内意義は, そのような system との関連性を含めて解析される必要性を示 唆するとも考えられた。

最後に, 私達はマウスの系において生体内におけ る rhG-CSF の抗腫瘍活性誘導について検討した。 リンパ腫細胞を接種した同系マウスに $\mathrm{rhG}-\mathrm{CSF}$ を 
単独投与することにより転移抑制と有意な survival の延長が認められた。その機序に関する現在までの 検討では, G-CSF 自体にはこれら腫瘍細胞にたいす る抗腫瘍活性はみられず, G-CSFにより活性化され た好中球を介した抗腫瘍性機序の可能性が強く推察 されている。マウスに打ける実験系を短絡的にヒト の腫瘍にアナロジーすることはできないが，ある種 のヒト悪性リンパ腫に拈いては rhG-CSF が BRM として抗腫瘍性に作用する可能性を示唆するものと 考えられた。

\section{文}

1) DeVita VT, Hubbard Jr. SM, Young RC, Longo $\mathrm{DL}$ : The role of chemotherapy in diffuse aggressive lymphomas. Semin Hematol 25 (Suppl 2) : 2-10 1988

2) Kobayashi M, Van Leeuwen BH, Elsbury S, Martinson SE, Young IG, Hapel AJ : Interleukin -3 is significantly more effective than other colony-stimulating factors in long-term maintenance of human bone marrow-derived colonyforming cells in vitro. Blood $73: 1836-1834$ 1989

3) Okabe M, Minagawa T, Nakane A, Sakurada $\mathrm{K}$, Miyazaki T:Impaired $\alpha$-interferon production and natural killer activity in blood mononuclear cells in myelodysplastic syndromes. Scand J Haematol 3:111-117 1986

4) Okabe M, Kunieda Y, Saiki I, Minagawa T, Miyazaki $\mathrm{T}$ : Inhibitory effect of interleukin-4 on the in vitro growth of $\mathrm{Ph}^{1}$-positive acute lymphoblastic leukemia cells. Blood 78 : 157415801991

5 ) Okabe M, Kobayashi M, Miyazaki T: Establishment and characterization of a cell line, TOM1, derived from a patient with Philadelphia chromosome-positive acute lymphocytic leukemia. Blood 69:990-998 1987

6) Nagata S, Tsuchiya M, Asano S, Kaziro Y, Yamazaki T, Yamamoto O, Hirata Y, Kubota $\mathrm{N}$, Oheda M, Nomura H, Ono M: Molecular cloning and expression of cDNA for human granulocyte colony stimulating factor. Nature

\begin{abstract}
謝
辞

本研究の一部において共同研究を頂いた前田史 郎, 板谷利幸, 国枝保幸（北大第三内科）各先生, IFN- $\alpha$ probe (Hif-2h plasmid) を御供与くだされ た長田重一博士（大阪バイオサイエンスセンター） に打礼申し上げます。稿を終えるにあたり，発表の 機会を与えていただいた宮㠃保会長ならびに座長の 労を拈とりいただいた下山正徳, 吉木敬両先生に深 謝申し上げます。
\end{abstract}

献

319:415-418 1986

7) Matsumoto Y, Saiki I, Murata J, Azuma I :rhG -CSF inhibits the metastasis of hematogenous and nonhematogenous tumors in mice. Int $\mathrm{J}$ Cancer 49 (in press) 1991

8 ）厚生省がん研究助成金 “我が国の B 細胞腫場の特性 とその診断, 治療及び病因解析に関する研究”班と “固形がんの集学的治療の研究”班の lymphoma study group（代表 下山正徳）：共通プロトコール LSG4

9) Fisher RI, DeVita VT Jr, Hubbard SM, : Randomized trial of ProMACE-MOPP vs. ProMACE-CytaBOM in previously untreated, advanced stage, diffuse aggressive lymphoma. Proc Am Soc Clin Oncol 3:242 1984 (abstr)

10) Lindemann A, Herrman F. Oster W, Haffner G, Meyenburg W, Souza LM, Mertelsmann R: Hematologic effects of recombinant human granulocyte colony-stimulating factor in patients with malignancy. Blood $74: 2644-2651$ 1989

11) Ohsaka A, Kitagawa S, Sakamoto S, Miura $Y$, Takanashi N, Takaku F, Saito $M$ : In vivo activation of human neutrophil functions by admistration of recombinant human granulocyte colony-stimulating factor in patients with malignant lymphoma. Blood 74 :2743-2748 1989

12) Shirafuji N, Matsuda H, Ogura H, Tani H, Ozawa K, Nagata S, Asano S, Takaku F: Granulocyte colony-stimulating factor stimulates human nature neutrophilic granulocytes to 
produce interferon- $\alpha$. Blood 75 : 17-19 1990

13) Lord PCW, Wilmoth LMG, Mizel SB, Mc Call: Expression of interleukin $-1 \alpha$ and $\beta$ genes by human blood polymorphonuclear leukocytes. J Clin Invest $87: 1312-13211991$

14) Lindemann $\mathrm{AD}$, Riedel $\mathrm{W}$, Oster $\mathrm{W}$, Loems Ziegler-Heitbrock HW, Mertersmann R, Hermann F: Granulocyte-macrophage colony-stimulating factor induces cytokine serection by human polymorphonuclear leukocytes. J Clin Invest $83: 1308-1312 \quad 1989$

15) Nagata S: Granulocyte colony-stimulating factor. Handbook of experimental Pharmacology, vol. 95/I. Peptide growth factors and their receptors (edited by Sporn $\mathrm{MB}$ and Roberts $\mathrm{AB}$ ) Springer-Verlag. Berlin 1990

16）尾山淳, 太田和雄, 浅野茂隆 他：Re-combinant Human G-CSF (rG-CSF 注)の臨床検討。 日癌治 $25: 1619-1634 \quad 1990$

17）小川一誠, 正岡徹, 高久史麿：悪性リンパ腫化学療法 後の白血球减少に対する KRN-8601の第 2 相試験 臨床医薬 $\quad 5: 2513-2529 \quad 1989$

18) Oda $M$, Satouchi $K$, Yasunaga $K$, Saito $K$ : Polymorphonuclear leukocyte-platelet interactions: Acetylglyceryl ether phosphocoline - induced platelet activation under stimulation with chemotactic peptide. J Biochem $100: 1117-1123$ 1986 